\title{
Arte, arquitetura, paisagem
}

Pedro Hussak (Universidade Federal Rural do Rio de Janeiro, Brasil) *

Flávia Oliveira (Universidade Federal do Rio de Janeiro, Brasil) **

Luciano Vinhosa (Universidade Federal Fluminense, Brasil) ${ }^{* * *}$

https://doi.org/10.22409/poiesis.v21i36.42732

Não é de se estranhar que um dos textos-chave para compreender a arte contemporânea, Escultura no campo ampliado de Rosalind Krauss (1978), seja na realidade uma discussão sobre a relação entre arte, arquitetura e paisagem. A crítica estadunidense constata uma transformação histórica na escultura que consistiu no fato de que escultores a partir dos anos 1950 começaram a retirar o pedestal do objeto escultórico. Se, por um lado, esse processo implicou em um questionamento mais geral do próprio médium tradicional da arte, abrindo, para o que se convencionou chamar de arte contemporânea, a possibilidade de se trabalhar com uma multiplicidade de suportes, por outro, ele gerou uma dificuldade no que tange ao problema de saber como a escultura poderia destacar-se dos demais objetos, dificultando o seu reconhecimento enquanto obra de arte. Nos anos 1960, muitos artistas, em particular aqueles da land art, produziram obras ao ar livre que visavam borrar as fronteiras entre uma forma escultórica e a paisagem.

\footnotetext{
* Pedro Hussak é Professor Associado de Estética na Universidade Federal Rural do Rio de Janeiro (UFRRJ). E-mail: phussak@gmail.com. Orcid: https://orcid.org/0000-0002-4907-9093

${ }^{*}$ Flávia Oliveira é Professora Adjunto da Faculdade de Arquitetura e Urbanismo da Universidade Federal do Rio de Janeiro (UFRJ). Email: flavia.olive@gmail.com. Orcid: https://orcid.org/0000-0001-7203-4507

**t Luciano Vinhosa é artista e Professor Associado da Universidade Federal Fluminense (UFF). E-mail: luciano.vinhosa@gmail.com. Orcid: https://orcid.org/0000-0001-8593-1223
} 
No entanto, embora tal mudança operada pela arte contemporânea tenha colocado questões relativas à relação entre arte, arquitetura e paisagem, é possível considerar que a colocação desse problema remeta ao século XVIII e a um debate no pensamento estético relativo à questão do Belo natural e do Belo artístico. Sem querer entrar nas querelas, por exemplo, de Kant e Hegel, sobre qual das duas é "superior", cabe salientar que esse problema se coloca porque não é possível pensar o "natural" e o "artificial" como duas esferas completamente separadas, em vez disso, elas deveriam ser complementares. Por isso, o século XVIII é também o século dos jardins, um espaço no qual há uma intervenção que visa controlar a natureza e produzir uma bela paisagem. Desta feita, a paisagem não é um elemento totalmente divorciada do toque da mão humana: a arte e a arquitetura sempre determinaram uma forma de olhar a paisagem natural, basta pensar, por exemplo, em muitos templos gregos que engendram uma relação entre o mar e a montanha. Em outras palavras, arte e arquitetura determinam uma forma de olhar a natureza, compondo assim uma paisagem.

Atravessados por essas questões, os organizadores não tiveram dificuldade em con- cordar que o melhor espaço para abrigar, em 28 de outubro de 2019, o seminário Arte contemporânea, arquitetura, paisagem, seria o Museu de Arte Contemporânea de Niterói. O museu, ao mesmo tempo, inserese na paisagem urbana da cidade e instaura uma relação com a Baía de Guanabara. O seminário foi a ocasião para as apresentações que serviram de base para este dossiê, assim como para discussões muito profícuas.

O texto Dois museus de arte no litoral como perguntas sobre experiência da arquitetura, da pesquisadora francesa Cécile Bourgade, que defendeu uma tese sobre Oscar Niemeyer na Université Paris 1 - Panthéon Sorbonne, versa justamente sobre essa característica do MAC-Niterói de ser um museu situado no litoral, o que Ihe dá a ocasião para fazer um estudo comparado com o Museu das Civilizações da Europa e do Mediterrâneo (MUCEM), também situado no litoral, na cidade francesa de Marselha.

Da mesma universidade francesa, o dossiê conta com a preciosa contribuição dos professores de estética e de filosofia da arte Gilles Tiberghien e Olivier Schefer. Com o texto Espaços liminares. Natureza e função

Pedro Hussak; Flávia Oliveira; Luciano Vinhosa, Arte, arquitetura, paisagem. 
do limiar na paisagem contemporânea, Schefer retoma a questão da paisagem e do limiar no romantismo alemão a partir da pintura de Caspar David Friedrich, para estabelecer paralelos com obras de arte contemporânea, em particular, com as de Simon Faithfull e Marylène Negro. Já $\operatorname{com} A$ Paisagem de ponta-cabeça, Gilles Tiberghien aborda a mudança de perspectiva no modo de perceber a paisagem, argumentando que em grande medida a compreensão da paisagem no ocidente foi construída na pintura renascentista a partir de um ponto de vista em que a linha do horizonte estruturava todo o campo visual do sujeito. Trata-se de abordá-la em outra chave, principalmente no âmbito de transformações ocorridas no século XIX, que consiste em percebê-la de um ponto de vista não horizontal, mas vertical, de cima para baixo.

As professoras da FAU-UFRJ Flávia Oliveira e Fabiola Zonno dão contribuições no sentido de adentrar nas margens instáveis entre arquitetura, arte e paisagem. Mobilizada pela questão da construção da memória na arquitetura, Fabíola Zunno faz uma análise da questão do monumento, tanto em escritos teóricos como em obras realizadas, do arquiteto suíço Peter Zumthor. Já Flávia
Oliveira propõe uma análise da exposição Le grand ensemble, na qual o artista francês Mathieu Pernot trabalha a partir de cartões postais de conjuntos habitacionais na França. A professora de teoria da arquitetura enfoca como o artista realiza a mudança de suporte, da exposição física para um livro de imagens.

A contribuição de Luciano Vinhosa, artista, teórico e professor de arte da Universidade Federal Fluminense, Do pequeno gesto ao monumento, também aborda os problemas relacionados à relação arte, arquitetura, monumento e antimonumento, ao comentar a exposição de mesmo nome que ele realizou na galeria do Museu Universitário de Arte (MUnA) da Universidade Federal de Uberlândia, Minas Gerais, em maio de 2019.

O seminário e o consequente dossiê somente foram possíveis graças a um grande esforço institucional. Cabe destacar que a participação dos acadêmicos franceses ocorreu no âmbito do projeto CAPESCOFECUB Estética contemporânea: diálogo de culturas, uma parceria entre a UFRRJ, a UFMG e a Université Paris 1 - PanthéonSorbonne. A organização do seminário e do 
dossiê ficou a cargo de Luciano Vinhosa, professor do PPGCA-UFF; Flavia Oliveira, professora da FAU-UFRJ e Pedro Hussak, professor do PPGFIL-UFRRJ e colaborador do PPGCA-UFF. Agradecemos ao MACNiterói, em nome de seu diretor, Marcelo Velloso, que gentilmente acolheu o seminá- rio. Agradecemos igualmente ao Programa de Pós-Graduação em Estudos Contemporâneos das Artes (PPGCA-UFF) e ao editor da Revista Poiésis, professor Luiz Sérgio de Oliveira, que gentilmente nos deu a oportunidade de publicarmos este dossiê.

Citação recomendada:

HUSSAK, Pedro; OLIVEIRA, Flávia; VINHOSA, Luciano. Arte, arquitetura, paisagem (apresentação do dossiê). Revista Poiésis, Niterói, v. 21, n. 36, p. 11-14, jul./dez. 2020. [https://doi.org/10.22409/poiesis.v21i36.42732]

\section{(cc) BY-NC-ND Este documento é distribuído nos termos da licença Creative Commons Atri-} buição-NãoComercial 4.0 Internacional (CC-BY-NC) (c) 2020 Os Autores 